\title{
Assessment of Risk Factors for Psychosocial Hazards among Workers in a Tertiary Institution in Nigeria: The Need for a Safer Work Environment
}

\author{
A. K. Nkporbu1* ${ }^{*}$ E. O. Asuquo², K. E. Douglas ${ }^{2}$ \\ ${ }^{1}$ Department of Neuropsychiatry, University of Port Harcourt Teaching Hospital, Port Harcourt, Nigeria \\ ${ }^{2}$ Department of Preventive and Social Medicine, University of Port Harcourt, Port Harcourt, Nigeria \\ Email: *nakpigi2008@yahoo.com
}

How to cite this paper: Nkporbu, A.K., Asuquo, E.O. and Douglas, K.E. (2016) Assessment of Risk Factors for Psychosocial Hazards among Workers in a Tertiary Institution in Nigeria: The Need for a Safer Work Environment. Open Access Library Journal, 3: e3104.

http://dx.doi.org/10.4236/oalib.1103104

Received: September 27, 2016

Accepted: October 25, 2016

Published: October 28, 2016

Copyright $\odot 2016$ by authors and Open Access Library Inc.

This work is licensed under the Creative Commons Attribution International License (CC BY 4.0).

http://creativecommons.org/licenses/by/4.0/ (c) (i) Open Access

\section{Abstract}

Background: Work place psychosocial hazards are assuming a central place in occupational health and safety, especially in developing countries like Nigeria. Psychosocial hazards refer to the mental stresses of work including all sources of fatigue and stress caused by work, work structure, design and regulation that affect output and employee's wellbeing and health. Several factors have been identified to increase the risks of psychosocial hazards. A number of risk factors may predispose workers to certain work place hazards. Aim: The study was to assess the possible risk factors for psychosocial hazards among Workers at the University of Port Harcourt. Methodology: Ethical approval for the study was obtained and 600 consenting staffers of the University of Port Harcourt were recruited by systematic random sampling and a risk Matrix which is a validated instrument (interviewer administered) as well as a pretested structured closed ended self administered questionnaire was distributed among respondents. Results were presented using descriptive and analytical methods. Results: From the study, risk factors for psychosocial hazards included work load with 548 (98.2\%), followed by home-work interface with 458 (82.0\%), lack of possibilities to advance forward 392 (70.1\%), lack of career development 327 (58.7\%), work content with 329 (60\%) while constant state of alertness (CSA) was the least with 98 (17.6\%). Conclusion: Workers at the University of Port Harcourt experienced or are faced with a number of risk factors for psychosocial hazards; most of them are organizational and employer's factors. Therefore there is a need to institute appropriate measures to address preventable risk factors and improve the work environment thereby increasing workers effectiveness, productivity and improving their health. 


\section{Subject Areas}

Psychiatry \& Psychology, Public Health

\section{Keywords}

Risk Factors, Psychosocial Hazards, Workers

\section{Introduction}

There exist constant competitions among organizations to maximize profit and minimize costs [1]. In the course of these, there is increased demand on the employee for higher productivity and greater accountability in the public sector, including public educational institutions, and greater profitability in the private sector [2]-[7]. Nowadays, workplace environments in both sectors have been increasingly characterized by heightened pressure on employees to perform at consistently higher levels, sometimes with longer hours, reduced staff numbers, insecure employment patterns and employer empowerment, with unmatched reward system [2]-[7].

All these factors have been identified to invariably contribute to creating a stressful and an unfriendly work environment and hence increase the risks of psychological problems [8]-[12]. Stress is now recognized in health and safety legislation as a workplace hazard, namely a "psychosocial hazard" [13] [14]. Psychosocial hazards are inherent in the total stress caused by work, work structure, design and regulation, and therefore are an integral part of an overall assessment of risks at work places.

Every kind of work is associated with its unique certain occupational risks [15] [16] [17]. The changing economic context has been associated with a shift in the types of risks encountered in the work environment, with new types of work place hazards emerging in addition to the traditional ones [18] [19]. Emerging workplace risks include psychosocial risks, as well as exposure to a number of new and emerging chemicals and processes of which the consequences for human health are still unknown [20].

There is an evident delay in controlling these modern and emerging risks particularly in developing countries, since many still struggle extensively with the more well-known traditional occupational risks [21]. These are increasingly controlled in industrialized countries, a fact which explains the switch of attention to the modern hazards of working life [22] [23] [24]. Physical risks and hazards not only interact with one another in producing adverse effects, but may also do so with psychosocial risks and hazards as well as physical and psychosocial conditions [25].

Broadly speaking, the term "psychosocial” refers to the interrelationships between individuals' thoughts and behaviours, and their social environment. In most literatures outside the Occupational Health and Safety (OHS) field, this term is often narrowly but diffusely viewed and refers to social environments such as family of origin, socioeconomic status and level of education [26]. Whilst it is important to take cognizance of 
individual and non-work psychosocial factors and environment, in the OHS context, psychosocial hazards have come to refer only to hazards created by work, work design, work structure and regulation and the entire work environment [26].

Psychosocial hazards consistently show enormous impact on workers' health, public health and business health [27]-[32]. Lost hours and absenteeism from work due to occupational injuries, ill health and work-related mental health problems are of growing concern globally. The health impact from psychosocial risks and work-related stress affects workers and their families, as well as businesses, since workers' illness is related to outcomes that can have financial impact on businesses [27] [28] [29] [30]. These variables include sickness absences, the hidden cost of presenteeism when a sick worker is present at work and not fully productive, and also unemployment. Effects are also visible at national and even global economic levels. Indeed, the cost of the work-related health loss and associated productivity loss represents around $4 \%-5 \%$ of the GDP of most countries [30] [31] [32] [33].

Several factors have been identified to increase the risks of psychosocial hazards [34] [35] [36] [37]. Some of them include changes in the working population, job content, workload, workplace and forced pace of work, work schedule, shift work, long work hours and overtime, extent of control, environment and equipment, organizational culture and function, interpersonal relationships at work (Relationships with Superiors, Subordinates and Colleagues), violence, threat of violence and bullying at work, role in organization, career development and home-work interface [37] [38] [39] [40] [41].

Recent studies indicate that contemporary and emerging psychosocial risks are changing and go beyond the traditional workplace-centered approach [34]. These include external factors such as globalization [42], increased vulnerability of workers in the context of globalization [42], precarious contracts, in the context of the unstable labor markets, new forms of employment contracts, and the feeling of job insecurity. Workers in developing countries often face combined risks of traditional and emerging risks, despite the fact that there is now widespread knowledge about these and effective preventive measures [43] [44] [45]. It seems, therefore, unfortunate that, in general, occupational health remains neglected in developing countries because of competing social, economic and political challenges [46]. The cycle of poverty clearly depicts the vicious cycle between poverty, ill-health and hazardous jobs in the absence of any kind of worker's protection.

The most studied core contributing factors to psychosocial risks and work-related stress have been found to be embedded in the work content and work context. At organizational and workplace levels, work content includes the nature of tasks, the workload and the pace of work, the number of hours worked, as well as the level of participation and control over the workload and work processes [47] [48]. Organizational and workplace level, work/job content have been found to be very important psychosocial risk factor. These include monotonous, under stimulating, meaningless tasks; lack of variety and unpleasant tasks. Workload and work pace has to do with having too much or too little to do and working under time pressures. Working hours involve strict and 
inflexible working schedules; long and unsocial hours; unpredictable working hours; and badly designed shift systems [49] [50].

On the other hand, work context refers to career development opportunities, status, the level of payment, the role in the organization and its level of clarity, interpersonal relationships (conflict, psychological harassment), the nature of the organizational culture, as well as the work-home interface in terms of support, conflicts and spill-over effects. Work context also covers career development, status and pay: job insecurity; lack of promotion prospects; under-promotion or over-promotion; work of 'low social value'; piece rate payments schemes; unclear or unfair performance evaluation systems; being over-skilled or under-skilled for the job [47] [48] [49] [50] [51].

Poor participation and control has equally been implicated as psychosocial stress [47]. Lack of participation in decision making and lack of control (for example, over work methods, pace, hours, environment) [35]. Role Designation in the organization is also important in the issue of work place psychosocial risk factors. Unclear role; conflicting roles within the same job; responsibility for people; continuously dealing with other people and their problems have all been found to be important psychosocial risk factors. Interpersonal relationships in terms of inadequate, inconsiderate or unsupportive supervision; poor relationships with co-workers; bullying, harassment and violence (including sexual harassment); isolated or solitary work; no agreed procedures for dealing with problems or complaints [52]. Psychosocial risks have previously been described as an integral element of the stress process, in terms of the interaction among job content, work organization and management, environmental and organizational conditions on the one hand, and the employees' competencies and needs on the other; an interaction that can prove to be hazardous to employees' health through their perceptions and experience [53].

Specifically, psychosocial risks in the workplace have been demonstrated to have a possible detrimental impact on workers' physical, mental and social health. In addition, a growing body of evidence indicates both a direct and indirect role of the psychosocial working environment on organisational health indices (such as absenteeism, sickness absence, productivity, job satisfaction and intention to quit) [54] [55] [56].

It has been noted that $80 \%$ of the global workforce resides in the developing world, and is subjected mostly to unhealthy and unsafe working conditions. Published studies point to the fact that traditional risks are intrinsically related to psychosocial risks, since both have the potential for detrimentally affecting social and psychological health as well as physical health [57] [58] [59] [60]. Therefore, psychosocial risks should be considered as risks to both, psychological and physical health [60].

There is currently lack of awareness and this makes most occurrences of work place bullying unnoticed or unattended to [61] [62]. The findings and knowledge from this study will help to create the awareness about psychosocial hazards among workers of the University, and equally afford them the ability to avoid them where and when necessary. The aim of this study therefore was to assess the prevalence and pattern of work place bullying among Workers at the University of Port Harcourt. 


\section{Methodology}

\section{Study Design}

This is a descriptive cross-sectional study.

\section{Study Area and Population}

This study was conducted among 600 workers of the University of Port Harcourt (UNIPORT). Participants were drawn from both academic and non-academic staff of the institution, across Colleges, Faculties, Schools and Departments. The University of Port Harcourt, formally known as University College Port Harcourt, is a federal tertiary institution of learning. It was established in 1975 by the Federal Government of Nigeria headed by General Olusegun Obasanjo and was given full University status in 1977. The Motto of the University is Self-reliance and Discipline. The University of Port Harcourt is located along the East-West Road, Choba Town in Obio-Akpor Local Government Area, adjacent the University of Port Harcourt Teaching Hospital, all in Rivers State of Niger Delta Region of Nigeria.

The University changed from school system to faculties in 1982. From the time the University was established as University College of Port Harcourt, it has grown from the status of six schools to four Colleges, nine Faculties and four Schools. The Colleges include health sciences, natural and applied sciences, engineering and continuous education while the faculties include those of humanities, pharmaceutical sciences, management sciences, social sciences, law, agriculture, basic medical sciences, clinical sciences and education.

The University currently has staff strength of about four thousand six hundred and fifty five workers catering for a student's capacity of between 60,000 to 70,000 . The University of Port Harcourt, being a federal public educational institution, its work force has been made to as much as possible reflect federal character. The staff categories are along academic and non-academic staff. The academic staff included graduate assistants, assistant lecturers, lecturers 1 and 2, senior lecturers, readers and professors, academic contract staff and those on sabbatical leave. The non-academic Departments/Units include those of Central Administration, Bursary, Library, Works, Security, Transport, Cleaners and Dispatchers. All academic staff are Senior staff while the non-academic staff are made up of both Junior and Senior staff. Majority of the study population were enlightened individuals with at least basic educational qualifications. Only bonafide staff of the University of Port Harcourt, Staff who have given their informed consent, Adults aged between 18 years and 70 years and those who had worked not less than 2 years in the University were included while casual staff and less than two years in employment were excluded.

\section{Sample Size and Sampling Methods}

The sample size was calculated using the formula for comparison of proportions by Araoye [63]. They consisted of 600 randomly selected staff of all cadres in the work places, made up of both junior and senior staff. A stratified method of sampling was used first and later followed by a systematic random sampling to identify each subject from the various Departments of University of Port Harcourt. This spanned over 12 
weeks from $2^{\text {nd }}$ of August, 2015 to $8^{\text {th }}$ of November, 2015.

\section{Study Instruments}

A well-structured open ended socio-demographic and study questionnaire designed by the authors was used. The structured questionnaire, which was self-administered, written in simple English and contained sections on socio-demography and was reliable. A Risk Matrix which is a validated risk assessment instrument (interviewer administered), was used to assess possible identified work place risk factors for psychosocial hazards. The criteria for choosing a likely risk factor using the Risk Matrix is that the worker must have experienced the risk factor at least once while working in the current employment. The socio-demographic questionnaire took on the average 4 minutes while the Risk Matrix took an average of 7 minutes for a respondent. A Walk through Survey which is an on the spot, impromptu, unannounced, uninformed, immediate assessment of any work place was also used. A pilot study was conducted three weeks preceding the commencement of the actual study using sampled population in the Rivers State University of Science and Technology, Port Harcourt, who satisfied the inclusion criteria, and these were not included in the main study.

\section{Data Management, Presentation and Analysis}

Analysis of results involved the use of the twentieth edition of the statistical package for social sciences (SPSS-20, 2014) software. Descriptive statistics was calculated for all variables. For continuous variables, means and standard deviations (SD) and analysis of variance were computed. For categorical variables, descriptive statistics included the numbers and proportions in each category. Frequency distributions and cross tabulations were generated and chi-square test of significance was calculated. The conventional $5 \%$ of level of significance was set. Confidence interval was set at $95 \%$ and P-value of less than 0.05 was considered statistically significant.

\section{Ethical Considerations}

Approval for the study was obtained from the Ethical Committee of the University of Port Harcourt. Consent was equally obtained from all participants. Health education and awareness was carried out for the participants after completing the questionnaires. Meetings were held with staff, management and both staff and management in that other, after the Walk Through Survey to intimate them of the outcome.

\section{Study Limitation}

The study was limited by the inability to use a walk through survey guide during the walk through survey and the risk matrix in the assessment of risk factors may have undermined the quality of this research work.

\section{Results}

\section{Socio-Demographic Characteristic of Respondents}

From the study, workers within the age group of 36 - 45 (68.3\%) and 26 - 45 (68\%) constituted the group that had experienced most of the psychosocial risk factors as staff of the institution, while the oldest age group, $66-75$ had the least with $31.6 \%$ ( $\mathrm{p}=$ $0.041 \%)$. Females $(80.7 \%)$ were more at risk than the males $(60.4 \%)$. Those who were 
divorced constituted the highest percentage of those who have experienced psychosocial risk factors with $80 \%$ followed by those who were separated from their spouse with $71.4 \%$ and the single with $69 \%$.

Those with Secondary education had the highest number of those who had experienced work place psychosocial hazards and this was statistically significant ( $\mathrm{p}=$ 0.001). Those who have being employed for 11 - 20 years $(67.9 \%)$, non-academic (70.1\%) and junior staff (83.3\%) and those living in rural areas (80.4\%) constituted greater numbers of those who had experienced psychosocial risk factors. However, none was statistically significant (see Table 1).

\section{Risk Factors for Psychosocial Hazards among Workers at the University of Port Harcourt}

From the study, the highest risk factors for psychosocial Hazards was work load with 548 (98.2\%), followed by home-work interface with 458 (82.0\%), lack of possibilities to advance forward 392 (70.1\%), lack of career development 327 (58.7\%), work content with $329(60 \%)$ while constant state of alertness (CSA) was the least with 98 (17.6\%) (see Table 2).

\section{Discussion}

From the study, the age group that had experienced or exposed to the most of risk factors for psychosocial hazards was age of 36 - 45 years, followed by that of 26 - 35 years. This are also the age groups that were most represented in the study. This is expected because this age ranges from the most active age of labour with possibly the highest experience and as such, they may be under active pressure to perform and deliver. It suffices to mention that most employers make this age range a criterion for employment [21]. This further lends credence to the earlier statement that organizations and indeed employers are in constant competition aimed at maximizing profit and minimising cost [1]. As such only vibrant and active young individuals who most likely will fall within the above age ranges stand the best chance to be employed. There was a statistically significant relationship between age and experience of work place risk factors for psychosocial hazards $(\mathrm{p}=0.041)$.

From the study, males were predominant. This is supported by previous study [41] [52]. This may equally simply reflect the recruitment pattern of the University. However, more females tended to have been faced with work place psychosocial risks than men reflecting reports in available literature [49]-[54] [58]. This relationship however was not statistically significant $(\mathrm{p}=0.972)$. Despite the fact that majority of the respondents were married, the single appeared to have recorded the highest exposure to and or experience of work place psychosocial risks. This may reflect the fact that singlehood may offer some subtle higher vulnerability to exposure to the different forms of psychosocial risks [39] [53] [58]. However, the relationship between marital status and experience of psychosocial hazards was not statistically significant $(\mathrm{p}=0.740)$.

Majority of the respondents had tertiary education reflecting the fact that this is a tertiary institution of learning and as such most of the recruitment will be based on 
Table 1. Socio-demographic characteristics of respondents.

\begin{tabular}{|c|c|c|c|c|}
\hline Variables & Frequency & $\begin{array}{l}\% \text { exposed } \\
\text { to risk }\end{array}$ & $\begin{array}{c}\% \text { not exposed } \\
\text { to risk }\end{array}$ & $\begin{array}{c}\text { Statistical Analysis } \\
\text { (ANOVA) }\end{array}$ \\
\hline \multicolumn{5}{|l|}{$\underline{\text { Age }}$} \\
\hline $18-25 \mathrm{yrs}$ & 50 & $26(52 \%)$ & $24(48 \%)$ & \multirow{6}{*}{$\begin{array}{c}\mathrm{df}=5 \\
\mathrm{p}=0.041\end{array}$} \\
\hline $26-35$ & 101 & $69(68 \%)$ & $32(32 \%)$ & \\
\hline $36-45$ & 199 & $136(68.3 \%)$ & $63(31.7 \%)$ & \\
\hline $46-55$ & 148 & $98(66.2 \%)$ & $50(33.9 \%)$ & \\
\hline $56-65$ & 41 & $16(39 \%)$ & $25(61 \%)$ & \\
\hline $66-75$ & 19 & $6(31.6 \%)$ & $13(68.4 \%)$ & \\
\hline \multicolumn{5}{|l|}{$\underline{\text { Gender }}$} \\
\hline Male & 299 & $187(62.5 \%)$ & $112(37.5 \%)$ & \multirow[t]{2}{*}{$\begin{array}{c}\mathrm{df}=1 \\
\mathrm{p}=0.972\end{array}$} \\
\hline Female & 259 & $209(80.7 \%)$ & $50(19.3 \%)$ & \\
\hline \multicolumn{5}{|l|}{$\underline{\text { Marital status }}$} \\
\hline Married & 452 & $273(60.4 \%)$ & $179(39.7 \%)$ & \multirow{5}{*}{$\begin{array}{c}\mathrm{df}=4 \\
\mathrm{p}=0.740\end{array}$} \\
\hline Single & 71 & $49(69 \%)$ & $22(31 \%)$ & \\
\hline Separated & 7 & $5(71.4 \%)$ & $2(28.6 \%)$ & \\
\hline Divorced & 15 & $12(80 \%)$ & $3(20 \%)$ & \\
\hline Widowed & 13 & $8(61.5 \%)$ & $5(38.5 \%)$ & \\
\hline \multicolumn{5}{|c|}{ Level of Education } \\
\hline Primary & 12 & $5(41.7 \%)$ & $7(58.3 \%)$ & \multirow{3}{*}{$\begin{array}{c}\mathrm{df}=2 \\
\mathrm{p}=0.001\end{array}$} \\
\hline Secondary & 45 & $34(75.6 \%)$ & $11(24.4 \%)$ & \\
\hline Tertiary & 501 & $308(61.5 \%)$ & $193(38.5 \%)$ & \\
\hline \multicolumn{5}{|l|}{$\underline{\text { Religion }}$} \\
\hline Christianity & 523 & $318(60.8 \%)$ & $205(39.2 \%)$ & \multirow{3}{*}{$\begin{array}{c}\mathrm{df}=2 \\
\mathrm{p}=0.07\end{array}$} \\
\hline Islam & 35 & $19(54.3 \%)$ & $16(45.7 \%)$ & \\
\hline Traditional & - & - & & \\
\hline \multicolumn{5}{|l|}{$\underline{\text { Tribe }}$} \\
\hline Ikwerre & 117 & $77(65.8 \%)$ & $40(34.2 \%)$ & \multirow{5}{*}{$\begin{array}{c}\mathrm{df}=4 \\
\mathrm{p}=0.038\end{array}$} \\
\hline Ogoni & 64 & $41(64.1 \%)$ & $23(35.9 \%)$ & \\
\hline Ijaw/Kalabari & 59 & $33(55.9 \%)$ & $26(44.1 \%)$ & \\
\hline Etche/Ogba & 34 & $15(44.1 \%)$ & $19(55.9 \%)$ & \\
\hline Others & 284 & $181(63.8 \%)$ & $103(36.3 \%)$ & \\
\hline \multicolumn{5}{|l|}{ Living place } \\
\hline Urban & 245 & $136(55.5 \%)$ & $109(44.5 \%)$ & \multirow{3}{*}{$\begin{array}{c}\mathrm{df}=2 \\
\mathrm{p}=0.236\end{array}$} \\
\hline Semi Urban & 211 & $125(59.2 \%)$ & $86(40.8 \%)$ & \\
\hline Rural & 102 & $82(80.4 \%)$ & $20(19.6 \%)$ & \\
\hline \multicolumn{5}{|c|}{ Employment Rank } \\
\hline Academic & 481 & $283(58.9 \%)$ & $198(41.2 \%)$ & $\mathrm{df}=1$ \\
\hline Non Academic & 77 & $54(70.1 \%)$ & $23(29.9 \%)$ & $\mathrm{p}=0.968$ \\
\hline \multicolumn{5}{|l|}{ Category of Staff } \\
\hline Junior Staff & 42 & $35(83.3 \%)$ & $7(16.7 \%)$ & $\mathrm{df}=1$ \\
\hline Senior Staff & 516 & $312(60.5 \%)$ & $204(39.6 \%)$ & $\mathrm{p}=0.985$ \\
\hline
\end{tabular}




\section{Continued}

Duration of Employment

\begin{tabular}{ccccc}
$2-10$ & 301 & $194(64.5 \%)$ & $107(35.5 \%)$ & \\
$11-20$ & 190 & $129(67.9 \%)$ & $61(32.1 \%)$ & \\
$21-30$ & 53 & $21(39.6 \%)$ & $32(60.4 \%)$ & $\mathrm{df}=5$ \\
$31-40$ & 14 & $3(21.4 \%)$ & $11(78.6 \%)$ & $\mathrm{p}=0.944$ \\
$41-50$ & - & - & & \\
$>50$ & - & - & & \\
\hline
\end{tabular}

Table 2. Showing likely risk factors of psychosocial hazards among workers at the University of Port Harcourt.

\begin{tabular}{|c|c|c|}
\hline S/N & Items & Percentage (\%) \\
\hline 1 & Changes in the working population (CWP) & $315(56.5)$ \\
\hline 2 & Job content (JC) & $329(60.0)$ \\
\hline 3 & Work load (WL) & $548(98.2)$ \\
\hline 4 & Work pace (WP) & $284(50.9)$ \\
\hline 5 & Forced pace of work (FPW) & $232(41.6)$ \\
\hline 6 & Work schedule : shift work, long work hours and overtime (WS) & $296(53.0)$ \\
\hline 7 & Control (c) & $216(38.7)$ \\
\hline 8 & Environment and equipment (EAE) & $306(54.8)$ \\
\hline 9 & Organizational culture and function (OCF) & $275(49.3)$ \\
\hline 10 & Interpersonal relationships at work (IRW) & $357(64.0)$ \\
\hline 11 & Violence, threat of violence and bullying at work (VTB) & $281(50.4)$ \\
\hline 12 & Role in organization (RIO) & $251(45.0)$ \\
\hline 13 & Lack of career development (CD) & $327(58.7)$ \\
\hline 14 & Home-work interface (HWI) & $458(82.0)$ \\
\hline 15 & Repetitive or monotonous work (RMW) & $189(33.9)$ \\
\hline 16 & Working alone or night work (WANW) & $121(21.7)$ \\
\hline 17 & Constant state of alertness (CSA) & $98(17.6)$ \\
\hline 18 & Social work load (SWL) & $203(36.3)$ \\
\hline 19 & Too busy (TB) & $241(43.1)$ \\
\hline 20 & Too high expectations or goals (THEG) & $258(46.2)$ \\
\hline 21 & Lack of possibilities to advance (LPA) & $392(70.1)$ \\
\hline 22 & Lack of job and workplace orientation (LJWO) & $270(48.4)$ \\
\hline 23 & Lack of job descriptions and responsibilities (LJDR) & $267(47.8)$ \\
\hline 24 & Uncertainty of employment (UE) & $113(20.1)$ \\
\hline 25 & Poor management or organization (PMO) & $304(54.5)$ \\
\hline 26 & Poor working atmosphere (PWA) & $219(39.2)$ \\
\hline 27 & Lack of interaction (LI) & $167(29.9)$ \\
\hline 28 & Lack of social support (LSS) & $182(32.6)$ \\
\hline 29 & Lack of possibilities to influence decision making (LPIDM) & $269(48.2)$ \\
\hline
\end{tabular}


possession of a tertiary level degree. This may also be related to why majority of the respondents were academic staff. The study found that those with lower levels of education (lower academic qualification refers to primary and secondary education) experience more psychosocial risk compared to those who possess higher academic qualifications. This may be a reflection of the fact those with higher level of education will naturally be placed at higher position and as such would play the role of bosses and have tendency to give order, command and possibly exert rulership which may sometimes be unfriendly over their subordinates. This finding is in line with existing literature that socioeconomic inequalities in work places may constitute psychosocial risk factors and tend to breed work place hazards [3] [39] [53]. The relationship between level of education and exposure to work place psychosocial risks was found to be statistically significant $(\mathrm{p}=0.001)$. This finding is consistent with previous studies which have noted that being faced with workplace psychosocial hazards is more prevalent in lower socioeconomic occupations and disadvantaged occupational classes [3] [61] [62], adding that indeed, the lower the socioeconomic position, the higher the risk of exposure to adverse and stressful working conditions [28] [29], and also more vulnerable to poorer health [27].

A number of risk factors were assessed ranging from changes in the working population, job content, work load, career development, home-work interface, lack of social support to lack of interactions. From the study, work load was identified as the most prevalent risk factor, followed by home-work interface, interpersonal relationship and job content while working alone at night was the least.

This finding is in line with earlier documentation that the most studied core contributing factors to psychosocial risks and work-related stress have been found to be embedded in the work content/load and work context [15]-[19] [33] [60]. However, new and precarious forms of contracts in the context of the unstable labour market (employment conditions), increased vulnerability of workers in the context of globalization, new forms of employment contracts, and the feeling of job insecurity have been identified as important emerging psychosocial risks [19] [20]. It has equally being found that where more of the contributing factors are present, increased levels of stress are likely to result due to synergism [20].

The content, context and volume of work which a worker has to do and accomplish within specified time has been found to be an important determinant of psychosocial hazard. This description is in line with a documented definition of work-related stress as a pattern of reactions that occurs when workers are presented with work demands not matched to their knowledge, skills or abilities and which challenge their ability to cope [13]; and when there is a perceived imbalance between demands and environmental or personal resources, reactions may include physiological responses (for example increased heart rate, blood pressure, hyperventilation, as well as secretion of "stress" hormones such as adrenaline and cortisol) [29] [31] [32], emotional responses (for example feeling nervous or irritated) [25] [26] [27], cognitive responses (for example, reduction or narrowing of attention and perception, forgetfulness), and behavioural 
reactions (for example aggressive, impulsive behaviour, making mistakes) [24] [28]. These may affect the work ability indices of the worker such as attention, concentration, focus and diligence and will certainly make the worker vulnerable to poor performance which may ensure certain forms of psychosocial hazards from their bosses or employers. In this case, mismatch between work content and context and the worker becomes a serious work place psychosocial risk factor.

Another important set of psychosocial risk factors are the narrow space and opportunity to develop in the service as seen in lack of career development, lack of opportunity to grow on the job and advance. This may sometime translate into lack of or delayed promotion. Worse still, at other times, a worker's promotion may be deliberately delayed or even stopped without any cogent reason or explanation. From the study, lack of opportunity for career development and job advancement were identified as important risk factors for psychosocial hazards by respondents. This is expected because a worker that is affected by any of the factors mentioned here will be wallowing in pain and will certainly lose all zeal to put in all his or her best due to lack of motivation [48]. As this happens, there will gradually be reduced productivity by the worker. This agrees with the proposition of Cox and Griffith that workers also have work-related stress when despite rendering perceived important work, there is all indication instead that their efforts are not adequately rewarded [11]. Appreciation and rewards even verbal are important motivating factors which fuel or increase performance.

The next risk factor that was found in this study was home-work interface. This risk factor mostly affects women and interestingly, work place psychosocial risks were more common among women than the men in this study. A number of studies have supported this finding [49] [50] [51] [58]. Women manage the home fronts and it has been said that they do thrice as much work as men. For these reasons, they may experience burnout easily than men.

From the Walk through Survey, it appears that the authorities of the University of Port Harcourt have made some efforts at development, particularly in infrastructure, even though there is no standard or ideal tertiary learning institution development scale at the author's disposal with which a comparison can be made. However, there still remains more to be done in terms of improvement of the work environment and worker's welfare. Importantly, these remain cardinal and key to worker's performance, health and wellbeing, quality of life and overall work productivity. Perhaps, this gap may have accounted for the presence of the various psychosocial hazards still being experienced by workers of the University of Port Harcourt.

\section{Conclusion}

All cadres of workers at the University of Port Harcourt are exposed to different forms of workplace psychosocial risks to various degrees; most of them are employers' and organizational factors. Therefore there is a need for the University to institute appropriate occupational health and safety measures to address preventable risk factors and reduce the harmful occurrences of psychosocial hazards in the institution in order to 
improve the working environment, productivity and health of workers.

\section{Recommendations}

Based on the findings from this study, they following are therefore recommended to the University management as appropriate measures and steps that could be taken to reduce the occurrence and burdens of psychosocial hazards in the University workplaces. They include the following:

1) The University should embark on periodic awareness-raising campaigns, and educational activities on prevailing occupational risk factors.

2) Regular Enlightenment of University workers (EUW) and special orientation programmes should be done for all newly employed staff.

3) Introduction of occupational health and safety programmes into the educational curriculum of the University. This will also provide avenues to acquire knowledge of occupational safety and health for both teaching and non-teaching staff, particularly those who may wish to take up one academic programme or the other within the University.

4) Immediate establishment of an Occupational risk and hazard management/Occupational rehabilitation centre.

5) The University should develop a welfare policy or scheme and set up a staff welfare management team to direct cater for the welfare of the workers.

\section{References}

[1] De Bruin, G.P. and Taylor, N. (2005) Development of the Sources of Work Stress Inventory. South African Journal of Psychology, 35, 748-765. http://dx.doi.org/10.1177/008124630503500408

[2] Melamed, S., Yekutieli, D., Froom, P., Kristal-Boneh, E. and Ribak, J. (1999) Adverse Work and Environmental Conditions Predict Occupational Injuries-The Israeli Cardiovascular Occupational Risk Factors Determination in Israel (CORDIS) Study. American Journal of Epidemiology, 150, 18-26. http://dx.doi.org/10.1093/oxfordjournals.aje.a009913

[3] Schrijvers, C.T.M., van de Mheen, H.D., Stronks K. and Mackenbach, J.P. (1998) Socioeconomic Inequalities in Health in the Working Population: The Contribution of Working Conditions. International Journal of Epidemiology, 27, 1011-1018. http://dx.doi.org/10.1093/ije/27.6.1011

[4] Takala, J. (2002) Life and Health Are Fundamental Rights for Workers (Interview). Labour Education, 1, 1-7.

[5] Dollard, M.F. (2006) Throwaway Workers. In Psych, 28, 8-12.

[6] Stebbins, P., Thatcher, S. and King, R. (Speakers) (2005) Work Related Stress: HR, OH\&S and Legal Strategy (CD Recording). Psychology Health Media, Brisbane.

[7] Dollard, M.F. and Walsh, C. (1999) Illusory Correlation: Is Work Stress Really Worse in the Public Sector? Journal of Occupational Health and Safety Australia and New Zealand, 15, 219-229.

Bonde, J.P. (2008) Psychosocial Factors at Work and Risk of Depression: A Systematic Review of the Epidemiological Evidence. Occupational \& Environmental Medicine, 65, 438445. http://dx.doi.org/10.1136/oem.2007.038430 
[8] Tennant, C. (2001) Work-Related Stress and Depressive Disorders. Journal of Psychosomatic Research, 51, 697-704. http://dx.doi.org/10.1016/S0022-3999(01)00255-0

[9] Melchior, M., Caspi, A., Milne, B.J., Danese, A., Poulton, R. and Moffitt, T.E. (2007) Work Stress Precipitates Depression and Anxiety in Young, Working Women and Men. Psychological Medicine, 37, 1119-1129. http://dx.doi.org/10.1017/S0033291707000414

[10] Warr, P.B. (1992) Job Features and Excessive Stress. In: Jenkins, R. and Coney, N., Eds., Prevention of Mental Ill Health at Work, HMSO, London, 201-205.

[11] Cox, T. and Griffiths, A. (2010) Work-Related Stress: A theoretical Perspective. In: Leka, S. and Houdmont, J., Eds., Occupational Health Psychology, Wiley-Blackwell, Chichester, 31-56.

[12] Bin Nordin, R., Bin Abdin, E. and Naing, L. (2008) Working Conditions, Self-Perceived Stress, Anxiety, Depression and Quality of Life: A Structural Equation Modelling Approach BioMedCentral (BMC) Public Health, 8, 4.

[13] Comcare (2006) What Is 'Stress' and What Is 'Psychological Injury'? http://www.comcare.gov.au/stress and psychological injury information portal/what is

[14] Sadock, V.J. and Sadock, V.A. (2007) Kaplan and Sadock's Synopsis of Psychiatry. 10th Edition, Lippincott Williams \& Wilkins, Philadelphia.

[15] Kortum, E. (2007) Work-Related Stress and Psychosocial Risks: Trends in Developing and Newly Industrialized Countries. The Global Occupational Health Network Newsletter, Special Issue, 3-6.

[16] Health \& Safety Executive (HSE) (2003) Psychosocial Risk Factors in Call Centres: An Evaluation of Work Design and Well-Being. Research Report 169. HSE Books, UK.

[17] Concha-Barrientos, M., Imel Nelson, D., Driscoll, T., Steenland, N.K., Punnett, L., Fingerhut, M.A., Prüss-Üstün, A., Leigh, J., Tak, S. and Corvalan, C. (2004) Selected Occupational Risk Factors. In: Ezzati, M., Lopez, A.D., Rodgers, A. and Murray, C.J.L., Eds., Comparative Quantification of Health Risks: Global and Regional Burden of Diseases Attributable to selected Major Risk Factors, WHO, Geneva, 1651-1801.

[18] Johnstone, R., Quinlan, M. and McNamara, M. (2011) OHS Inspectors and Psychosocial Risk Factors: Evidence from Australia. Safety Science, 49, 547-557. http://dx.doi.org/10.1016/j.ssci.2010.09.016

[19] Quinlan, M., Mayhew, C. and Bohle, P. (2001) The Global Expansion of Precarious Employment, Work Disorganization, and Consequences for Occupational Health: A Review of Recent Research. International Journal of Health Services, 31, 335-414. http://dx.doi.org/10.2190/607H-TTV0-QCN6-YLT4

[20] EU-OSHA (2007) Expert Forecast on Emerging Psychosocial Risks Related to Occupational Safety and Health. Office for Official Publications of the European Communities, Luxembourg.

[21] Kivimäki, M., Vahtera, J., Virtanen, M., Elovaino, M., Pentti, J. and Ferri, J.E. (2003) Temporary Employment and Risk of Overall and Cause Specific Mortality. American Journal of Epidemiology, 158, 663-668. http://dx.doi.org/10.1093/aje/kwg185

[22] Spurgeon, A., Harrington, J.M. and Cooper, C.L. (1997) Health and Safety Problems Associated with Long Working Hours: A Review of the Current Position. Occupational \& Environmental Medicine, 54, 367-375. http://dx.doi.org/10.1136/oem.54.6.367

[23] Vahtera, J., Pentti, J. and Kivimäki, M. (2004) Sickness Absence as a Predictor of Mortality among Male and Female Employees. Journal of Epidemiology \& Community Health, 58, 321-326. http://dx.doi.org/10.1136/jech.2003.011817 
[24] van den Berg, T.I.J., Elders, L.A.M., de Zwart, B.C.H. and Burdorf, A. (2009) The Effects of Work-Related and Individual Factors on the Work Ability Index: A Systematic Review. Occupational \& Environmental Medicine, 66, 211-220.

http://dx.doi.org/10.1136/oem.2008.039883

[25] Wieclaw, J., Agerbo, E., Mortenesen, P.B., Burr, H., Tuchsen, F. and Bonde, J.P. (2008) Psychosocial Working Conditions and the Risk of Depression and Anxiety Disorders in the Danish Workforce. BMC Public Health, 8, 280.

[26] Stansfeld, S. and Candy, B. (2006) Psychosocial Work Environment and Mental Health-A Meta-Analytic Review. Scandinavian Journal of Work Environment and Health, 32, 443462. http://dx.doi.org/10.5271/sjweh.1050

[27] Rydstedt, L.W., Ferrie, J. and Head, J. (2006) Is There Support for Curvilinear Relationships between Psychosocial Work Characteristics and Mental Well-Being? Cross-Sectional and Long-Term Data from the Whitehall II Study. Work \& Stress, 20, 6-20. http://dx.doi.org/10.1080/02678370600668119

[28] Ettner, S.L. and Grzywacz, J.G. (2001) Workers' Perceptions of How Jobs Affect Health: A Social Ecological Perspective. Journal of Occupational Health Psychology, 6, 101-113. http://dx.doi.org/10.1037/1076-8998.6.2.101

[29] Bosma, H., Peter, R., Siegrist, J. and Marmot, M. (1998) Two Alternative Job Stress Models and the Risk of Coronary Heart Disease. American Journal of Public Health, 88, 68-74. http://dx.doi.org/10.2105/AJPH.88.1.68

[30] Chen, W.Q., Yu, I.T.S. and Wong, T.W. (2005) Impact of Occupational Stress and Other Psychosocial Factors on Musculoskeletal Pain among Chinese Offshore Oil Installation Workers. Occupational \& Environmental Medicine, 62, 251-256. http://dx.doi.org/10.1136/oem.2004.013680

[31] László, K.D., Ahnve, S., Hallqvist, J., Ahlbom, A. and Janszky, I. (2010) Job Strain Predicts Recurrent Events after a First Acute Myocardial Infarction: The Stockholm Heart Epidemiology Program. Journal of Internal Medicine, 267, 599-611. http://dx.doi.org/10.1111/j.1365-2796.2009.02196.x

[32] Greenlund, K., Liu, K., Knox, S., McCreath, H., Dyer, A. and Gardin, J. (1995) Psychosocial Work Characteristics and Cardiovascular Disease Risk Factors in Young Adults: The CARDIA Study. Social Science \& Medicine, 41, 717-723. http://dx.doi.org/10.1016/0277-9536(94)00385-7

[33] Rydstedt, L.W., Johansson, G. and Evans, G.W. (1998) A Longitudinal Study of Workload, Health and Well-Being among Male and Female Urban Bus Drivers. Journal of Occupational \& Organizational Psychology, 71, 35-45. http://dx.doi.org/10.1111/j.2044-8325.1998.tb00661.x

[34] World Health Organization (2007) Global Plan of Action for Workers' Health, 2008-2017. WHO, Geneva, Switzerland.

[35] Kamusora, P. (2006) Non-Decision Making in Occupational Health Policies in Developing Countries. International Journal of Occupational and Environmental Health, 12, 65-71. http://dx.doi.org/10.1179/oeh.2006.12.1.65

[36] Awoyemi, A.O. and Kabir, M. (1997) Awareness about Occupational Hazards among Doctors at a Hospital in Nigeria. Bioscience Research Communication, 9, 183-187.

[37] Einarsen, S., Raknes, B.I. and Matthiesen, S.M. (1994) Bullying and Harassment at Work and Their Relationships to Work Environment Quality: An Exploratory Study. The European Work and Organizational Psychologist, 4, 381-401. http://dx.doi.org/10.1080/13594329408410497 
[38] Hoel, H., Sparks, K. and Cooper, C. (2001) The Cost of Violence/Stress at Work and the Benefits of a Violence/Stress-Free Working Environment. Report commissioned by the International Labour Organization, University of Manchester.

[39] Ortega, A., Høgh, A., Pejtersen, J.H., Feveile, H. and Olsen, O. (2009) Prevalence of Workplace Bullying and Risk Groups: A Representative Population Study. International Archives of Occupational \& Environmental Health, 82, 417-426.

http://dx.doi.org/10.1007/s00420-008-0339-8

[40] Rospenda, K. (2002) Workplace Harassment, Services Utilization, and Drinking Outcomes. Journal of Occupational Health Psychology, 7, 141-155. http://dx.doi.org/10.1037/1076-8998.7.2.141

[41] Baker, C.N. (2005) Blue-Collar Feminism: The Link between Male Domination and Sexual Harassment. In: Gruber, J.E. and Morgan, P., Eds., The Company of Men: Male Dominance and Sexual Harassment, Northeastern University Press, Boston, 242-270.

[42] Wegman, D.H. (2006) Aging and Globalization. Medicina del Lavoro, 97, 137-142.

[43] EU-OSHA (2009) OSH in Figures: Stress at Work-Facts and Figures. Office for Official Publications of the European Communities, Luxembourg.

[44] EU-OSHA (2002) How to Tackle Psychosocial Issues and Reduce Work-Related Stress. Office for Official Publications of the European Communities, Luxembourg.

[45] Cox, T. and Griffiths, A. (2000) Occupational Stress Interventions. HSE Books, Sudbury.

[46] Nuwayhid, I.A. (2004) Occupational Health Research in Developing Countries: S Partner for Social Justice. America Journal of public Health, 94, 1996-1921.

[47] Fischer, F.M., Oliveira, D.C., Nagai, R., Teixeira, L.R., Lombardi Jr., M., Latorrec, M.R.D.O. and Cooper, S.P. (2005) Job Control, Job Demands, Social Support at Work and Health among adolescent Workers. Revista de Saúde Pública, 39, 245-253. http://dx.doi.org/10.1590/s0034-89102005000200016

[48] Stillwell, B. (2001) Health Worker Motivation in Zimbabwe. Internal Report for the Department of Organization and Healthcare Delivery, World Health Organization, Geneva.

[49] Smyre, P. (1992) Women and Health. Women and World Development Series.

[50] Messing, K. (1998) One Eyed Science: Occupational Health and Women Workers. Temple University Press, Philadelphia.

[51] Zahm, S.H. (2000) Women at Work. In: Goldman, M.B. and Hatch, M.C., Eds., Women and Health, Academic Press, San Diego, 441-445.

http://dx.doi.org/10.1016/B978-012288145-9/50040-1

[52] Premji, S. (2011) Building Healthy and Equitable Workplaces for Women and Men: A Resource for Employers and Workers Representatives. Protecting Workers' Health Series No. 11, World Health Organization, Geneva.

[53] Duxbury, L. and Higgins, C. (2001) Work-Life Balance in the New Millennium: Where Are We? Where Do We Need to Go? CPRM Discussion Paper No. W|12, Canadian Policy Research Network, Ottawa.

[54] Siegrist, J. and Marmot, M. (2004) Health Inequalities and the Psychosocial EnvironmentTwo Scientific Challenges. Social Science \& Medicine, 58, 1463-1473. http://dx.doi.org/10.1016/S0277-9536(03)00349-6

[55] Borritz, M., Rugulies, R., Bjorner, J.B., Villadsen, E., Mikkelsen, O.A. and Kristensen, T.S. (2006) Burnout among Employees in Human Service Work: Design and Baseline Findings of the PUMA Study. Scandinavian Journal of Public Health, 34, 49-58.

http://dx.doi.org/10.1080/14034940510032275 
[56] Dollard, M.F. and Karasek, R. (2010) Building Psychosocial Safety Climate: Evaluation of a Socially Coordinated PAR Risk Management Stress Prevention Study. In: Houdmont, J. and Leka, S., Eds., Contemporary Occupational Health Psychology: Global Perspectives on Research and Practice, Wiley-Blackwell, Oxford, 208-234. http://dx.doi.org/10.1002/9780470661550.ch11

[57] Schrijvers, C.T.M., van de Mheen, H.D., Stronks, K. and Mackenbach, J.P. (1998) Socioeconomic Inequalities in Health in the Working Population: The Contribution of Working Conditions. International Journal of Epidemiology, 27, 1011-1018.

http://dx.doi.org/10.1093/ije/27.6.1011

[58] Nilvarangkul, K., Wongprom, J., Tumnong, C., Supornpun, A., Surit, P. and Srithongchai, N. (2006) Strengthening the Self-Care of Women Working in the Informal Sector: Local Fabric Weaving in Khon Kaen, Thailand (Phase I). Indian Health, 44, 101-107. http://dx.doi.org/10.2486/indhealth.44.101

[59] Polanyi, M. and Tompa, E. (2004) Rethinking Work-Health Models for the New Global Economy: A Qualitative Analysis of Emerging Dimensions of Work. Work. Journal of Prevention, Assessment \& Rehabilitation, 23, 3-18.

[60] Rosengren, A., Hawken, S., Ounpuu, O., Sliwa, K., Zubaid, M., Almahmeed, W.A., Blacket, K.N., Sitthi-Amorm, C., Sato, H. and Yusuf, S. (2004) Association of Psychosocial Risk Factors with Risk of Acute Myocardial Infarction in 11119 Cases and 13648 Controls from 52 Countries (the INTERHEART Study): Case Control Study. The Lancet, 364, 953-962. http://dx.doi.org/10.1016/S0140-6736(04)17019-0

[61] Wright, E.O. (1997) Forgotten Families: Ending the Growing Crisis Confronting Children and Working Parents in the Global Economy. Oxford University Press, New York.

[62] Chandola, T. and Jenkinson, C. (2000) The New UK Statistics Socio-Economic Classification (NS-SEC); Investigating Social Class Differences in Self-Reported Health Status. Journal of Public Health, 22, 182-190. http://dx.doi.org/10.1093/pubmed/22.2.182

[63] Araoye, M.O. (2004) Research Methodology with Statistics for Health and Social Science. Nathadex Publishers, 117-120.

\section{Submit or recommend next manuscript to OALib Journal and we will provide best} service for you:

- Publication frequency: Monthly

- 9 subject areas of science, technology and medicine

- Fair and rigorous peer-review system

- Fast publication process

- Article promotion in various social networking sites (LinkedIn, Facebook, Twitter, etc.)

- Maximum dissemination of your research work

Submit Your Paper Online: $\underline{\text { Click Here to Submit }}$

Or Contact service@oalib.com 